\title{
A Scientometric Review of Research Status on Unfrozen Soil Water
}

\author{
Shuna Feng ${ }^{1}$, Huan Zhang ${ }^{1}$, Jialong Lv $^{1,2}{ }^{,}$Miles Dyck ${ }^{3}$, Qingbai Wu ${ }^{4}$ and Hailong He ${ }^{1, *(D)}$ \\ 1 College of Natural Resources and Environment, Northwest A\&F University, Yangling 712100, Shaanxi, China; \\ fsn2945074751@nwafu.edu.cn (S.F.); ZH_2020@nwafu.edu.cn (H.Z.); lj1l1@nwafu.edu.cn (J.L.) \\ 2 Key Laboratory of Plant Nutrition and the Agri-Environment in Northwest China (Ministry of Agriculture), \\ Northwest A\&F University, Yangling 712100, Shaanxi, China \\ 3 Department of Renewable Resources, University of Alberta, Edmonton, AB T6G 2H1, Canada; \\ miles.dyck@ualberta.ca \\ 4 State Key Laboratory of Frozen Soil Engineering, Northwest Institute of Eco-Environment and Resources, \\ Chinese Academy of Sciences, Lanzhou 730000, Gansu, China; qbwu@lzb.ac.cn \\ * Correspondence: hailong.he@hotmail.com
}

Citation: Feng, S.; Zhang, H.; Lv, J.; Dyck, M.; Wu, Q.; He, H. A Scientometric Review of Research Status on Unfrozen Soil Water. Water 2021, 13, 708. https://doi.org/ 10.3390/w13050708

Academic Editor: Renato Morbidelli

Received: 4 February 2021

Accepted: 2 March 2021

Published: 5 March 2021

Publisher's Note: MDPI stays neutral with regard to jurisdictional claims in published maps and institutional affiliations.

Copyright: (c) 2021 by the authors. Licensee MDPI, Basel, Switzerland. This article is an open access article distributed under the terms and conditions of the Creative Commons Attribution (CC BY) license (https:// creativecommons.org/licenses/by/ $4.0 /)$.

\begin{abstract}
Unfrozen soil water affects the physical, chemical, hydrological, and mechanical properties of frozen soils, and climate change makes these relationships more complicated. The objective of this study was to investigate the research status of unfrozen soil water using scientometrics. Publications on unfrozen water in frozen soil (UWFS) retrieved from the Web of Science were analyzed with scientometric software tools including VOSviewer, CiteSpace, and HistCite Pro. The annual publication trend, co-authorship of authors, organizations, and countries, and the co-occurrence of keywords were analyzed. The most utilized journals and high-impact publications were identified. The results showed that 2007 (the year the "Bali Road Map" was released) represents a turning point (from slow to rapid) in the development of research on unfrozen water in frozen soil. Researchers and organizations from China and the United States are the major contributors, while Cold Regions Science and Technology is the most utilized journal for publishing research pertaining to UWFS. Currently, there is still a lack of reliable and user-friendly methods and techniques for measuring unfrozen water content. Future efforts are required to understand the mechanisms governing the magnitude of unfrozen water content and to develop new approaches to accurately and rapidly measure unfrozen water content in both laboratory and in situ.
\end{abstract}

Keywords: bibliometric analysis; science mapping; VOSviewer; HistCite Pro; frozen soils; liquid water

\section{Introduction}

Frozen soil, which is defined as a complex system of rock or soil containing ice at temperature of $0{ }^{\circ} \mathrm{C}$ or below, is distributed worldwide [1]. Frozen soil can be divided into permafrost and seasonal frozen soil according to the time period of freezing/thawing processes. Permafrost remains in a frozen state for more than two consecutive years with the top layer (also referred to as active layer) thawing in summer and refreezing in winter, while seasonally frozen soil only freezes in winter [2-4]. Over 55\% of the land surface in the Northern Hemisphere undergoes seasonal freeze-thaw cycles and over 25\% is occupied by permafrost $[5,6]$. It has long been recognized that unfrozen water (or liquid water) and ice coexist in frozen soils at subfreezing temperatures [7-9], even as low as $-70{ }^{\circ} \mathrm{C}$ ) [10]. The primary factor determining the magnitude of liquid water remaining unfrozen in frozen soils is temperature, followed by pressure, solute concentration, soil texture, and structure [11]. The coexistence of ice and unfrozen water remarkably influences the physical, chemical, hydraulic, and mechanical properties of frozen soil [12-16]. For instance, the phase change of unfrozen water to ice increases heat transport (thermal conductivities of ice and water are 2.2 and $0.6 \mathrm{~W} \mathrm{~m}^{-1} \mathrm{~K}^{-1}$, respectively) $[17,18]$, reduces 
hydraulic conductivity and permeability because ice impedes water flow [19], and increases soil strength [20]. Soil freeze-thaw dynamics result in a phase change between unfrozen water and ice [13,21], hydrothermal migration [22,23], release of greenhouse gas(es) [24], and salt accumulation $[25,26]$ that alter energy and mass exchange at the soil-atmosphere interface. Frozen soil, therefore, impacts agricultural, engineering, and environmental practices and socio-economic development in cold regions [12,14,27-33]. Global climate change makes its effects more complicated [2,29,34-38].

The key to frozen soil studies is the determination of unfrozen water and ice content. Therefore, numerous efforts have been made to develop methods and instruments $[13,15,39-43]$ to measure unfrozen water content and/or ice content. These achievements make it easier to investigate freeze-thaw effects on a wide range of soil processes and properties. However, there is a lack of overview on the research status of unfrozen water content at present, for the novice and expert alike. Scientometrics or bibliometric analysis is a scientific statistic and quantitative assessment of publications within a particular subject matter, based on data from citation indices [44,45]. It can be used to retrieve articles of interest, to identify research hotspots and seminal studies, to locate journals to read from or subscribe to, and to analyze interrelationships among authors from different institutions and countries, as well as schools of thought, etc. Scientometrics has been widely used to investigate the research progress in various disciplines, including soil science and hydrology [45-47]. However, to our knowledge, no such study has been conducted for unfrozen water in frozen soils (UWFS). The objective of this study was, therefore, to analyze the research status of publications on UWFS using scientometrics. Approaches including the co-authorship network visualization map, the citation network visualization map, cluster density visualization map, and the strongest citation bursts map were used to investigate global research trends in terms of publication volume, authors, institutions, countries, journals, and keywords. Discussions on the limitations of and applications in research of UWFS as well as perspectives on future studies are also given.

\section{Materials and Methods}

The Science Citation Index Expanded (SCI-EXPANDED) database of the Web of Science Core Collection (WoSCC) contains literature data since 1992. The data between 1992 and 2020 was downloaded from the WoSCC on January 20, 2021 for analysis. The query sets used for the literature search are: "TS $=$ (soil) AND TS $=$ (subfreezing OR freezing OR thawing OR melting OR frozen OR freeze-thaw cycle OR freeze/thaw OR * frost) AND TS = (liquid water content OR unfrozen water content OR ice content)", where TS indicates "topics" on the Web of Science. The search results were further restricted by languages and document types, so that only articles, letters, notes, books, book chapters, data papers, database reviews, and reviews written in English were retrieved. This search process returned a total of 1117 publications and they were saved as text files containing "full record with citation data". Each publication was then carefully reviewed to ensure that the majority pertained to unfrozen water content, a total of 719 publications were retained for scientometric analysis.

VOSviewer 1.6.15 [48] (The Centre for Science and Technology Studies, Leiden, Netherlands), CiteSpace 5.7.R1 [49] (Drexel University, Philadelphia, PA, USA), and HistCite Pro that was modified from the out-of-service HistCite [50,51] were used to perform scientometric analysis. VOSviewer 1.6.15, a Java-based software developed in 2009 by Eck and Waltman [48], is a tool for building and visualizing a scientometric network, which can quickly observe knowledge and research of a specific field. It was used to export the author collaboration network, the citation network, and density visualization map of keywords. Indices of VOSviewer include links (L, connection or a relation between investigated authors, countries or organizations) and total link strength (TLS). It was used to export the author collaboration network, the citation network, and density visualization map of keywords. HistCite Pro can be used to count the number of publications $(\mathrm{N})$, total local citation score (TLCS, times cited by the 719 publications), and total global citation score (TGCS, times 
cited by the WoSCC), as well as to identify the high-impact studies in this field. CiteSpace is a software tool to present the rules and structure of scientific knowledge, which is used to analyze burst time of a keyword that reflects the development and revolution of research hotspots. "Burst time," indicates a time period when a keyword shows significant increase in publications. OriginPro 9.0 (OriginLab Corporation, Northampton, MA, USA) was used to illustrate annual change of publication volume on unfrozen soil water.

\section{Results and Discussion}

\subsection{Annual Publication Trend}

Using scientometrics, we can better understand the development of research on UWFS by examining the annual volume of papers published on the subject. Figure 1 shows the major research areas and annual number of publications from January 1992 to December 2020. These publications were generally from the Web of Science categories of geology $(\mathrm{N}=332)$, engineering $(\mathrm{N}=231)$, environmental sciences ecology $(\mathrm{N}=149)$, water resources $(\mathrm{N}=112)$, agriculture $(\mathrm{N}=99)$, and physical geography $(\mathrm{N}=98)$. Note that the total numbers of publications in these six categories are greater than 719 , because some journals belong to two or more categories. In general, the annual number of publications shows an upward trend with some fluctuations. Between 1992 and 2007, the number of publications pertaining to UWFS was $<20$ per annum. However, 2007 marked an inflection point. Since that year, the number of publications on the subject has increased significantly, with a maximum of 99 publications in 2020 (Figure 1). The uptick in research on UWFS coincides with the release of "The Road Bali Map" [52,53], a two-year process of climaterelated initiatives and commitments adopted by the United Nations toward finalizing a binding climate agreement at the 2009 United Nations Climate Change Conference. It would suggest that 2007 marks a period when climate change gained political and environmental recognitions with increased research interest in frozen soils as indicated by topics related to permafrost thaw and greenhouse gas emissions. Additional reasons for the increase in research on frozen soil are likely related to the overall increase in the volume of research journals pertaining to the subject matter, e.g., The Cryosphere.

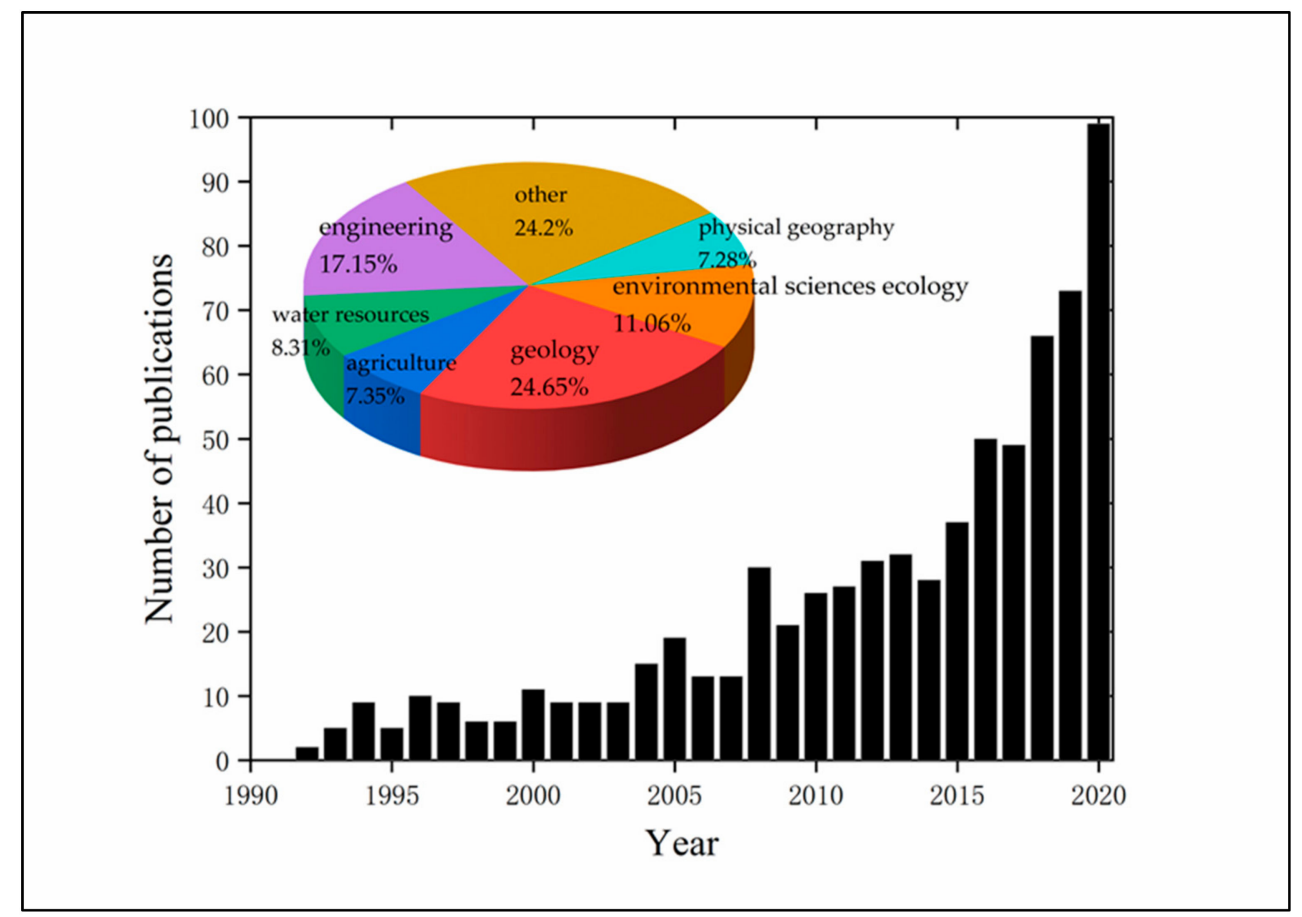

Figure 1. Number of annual publication on unfrozen water in frozen soils (UWFS) from January 1992 to December 2020 of Web of Science Core Collection. The pie chart is the top six major research areas. 


\subsection{Co-Authorship of Authors, Organizations and Countries}

A total of 2023 authors participated in studies of UWFS. The top 10 authors are mainly from China, the United States, and Canada (Table 1). Figure 2 shows that there are 18 groups or clusters (i.e., the same color) of authors that have at least five publications on UWFS. Among them, eight groups of authors have co-operative relationships as their nodes connect (Figure 2). These authors demonstrate different impact as well. For instance, Dr. Yuanming Lai from the Chinese Academy of Science (Lanzhou, China) ranked first in terms of the number of publications $(\mathrm{N}=19)$ and total local citation score (TLCS $=76)$, which indicates the times cited by the 719 publications retrieved for analysis. The high TLCS indicates that the publications of Dr. Lai were highly cited by researchers investigating UWFS (Table 1). Dr. Yuri Shur from the University of Alaska Fairbanks has the highest total global citation score (TGCS), which indicates that his publications were highly cited by research beyond this field (Table 1). Dr. Lin Zhao (Chinese Academy of Science) has greater total link strength (TLS) according to VOSviewer results (Table 1), suggesting that he has more coauthored publications. They lead the top three most productive teams in studies pertaining to UWFS.

The top 10 organizations belong to countries such as China, the United States, Russia, Canada, and Japan. The Chinese Academy of Sciences ranked first. It should also be noted that there are five authors who belong to the same institute (Table 1), which suggests a high level of expertise and overall experience for the Chinese Academy of Science in studies of frozen soil. Similarly, the same institute had the highest total for publications and the highest TCGS, which may be related to the fact that over $75 \%$ of China's landmass is affected by seasonally frozen soil and permafrost [54,55]. It is noteworthy that the number of publications from the University of Alaska (United States) ranked second, but their average indices are relatively higher, which may indicate that their publications have greater impact on studies of UWFS and other fields as well (Table 1).

All the 44 countries in the world that contributed to the study of frozen soils are widely distributed in the middle to high latitudes in the northern hemisphere. The majority of landmass in China, the United States, Canada, Japan, and Russia are subjected to seasonal freeze-thaw cycles or occupied by permafrost [5]. As the increasing concern of climate change on permafrost thaw or degradation $[56,57]$ and its feedback to climate and engineering applications, it is not surprising to notice that these countries published the most studies on UWFS (Table 1). Prior to 1992, many pioneering working in Russia, Canada, the United States, and many European countries greatly promoted the study of frozen soil, including the mechanism of liquid water phase transition [58,59], measurement methods [43,60], and engineering applications [61], which was also related to the development plan for frozen soil areas in these countries at that time. For instance, the increasing research in China from the 1990s may be closely related to engineering projects $[62,63]$, such as the construction and maintaining of the Qinghai-Tibet Railway [64] and Highway [65-67].

Figure 3 shows the mutual citation relationship among the 23 countries with minimum five publications. China, the United States, and Japan have published a large number of articles in this field (Table 1, Figure 3), which may represent that they have a greater impact in this field. In addition, China, the United States, and Canada have stronger collaborative relationships as indicated by the thicker lines between them compared with other countries (Figure 3). 


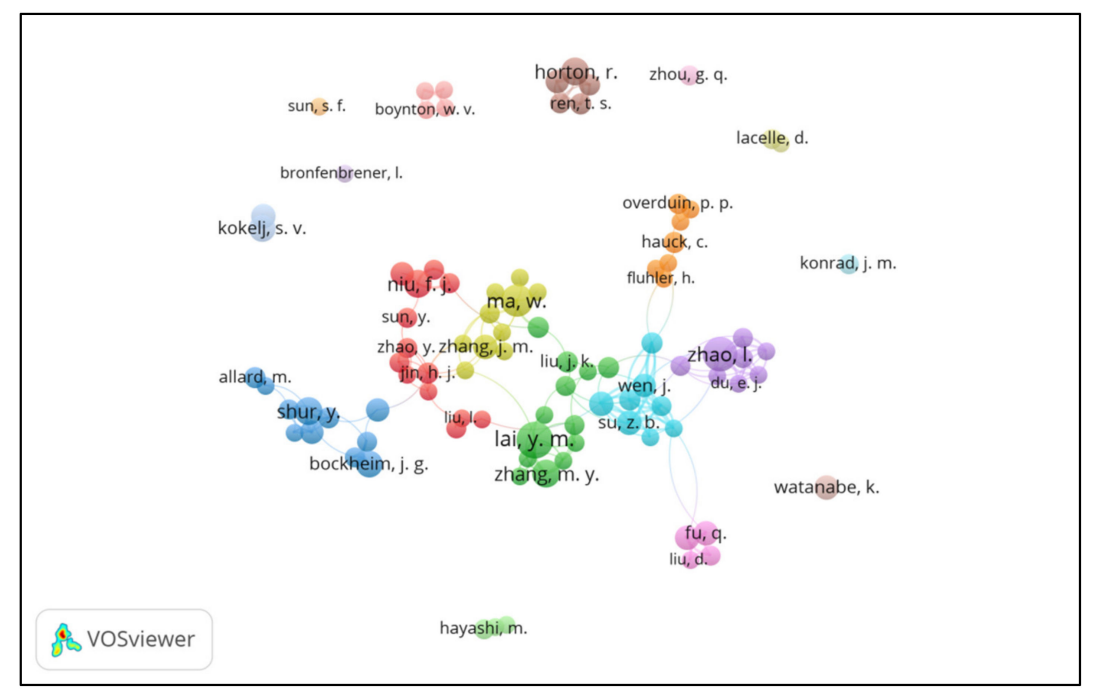

Figure 2. The co-authorship network visualization map of 95 authors out of 2023 authors with more than five publications as produced by VOSviewer. The size of circle and font in the map depends on the degree of nodes, the strength of links, and the amount of citations. The color of a circle represents the cluster to which it belongs and different clusters are represented by different colors.

Table 1. Top 10 authors, organizations, and countries published publications of unfrozen water in the frozen soil (UWFS). HistCite Pro is used to analyze and count the number of publications (N), total local citation score (TLCS), and total global citation score (TGCS). VOSviewer is used to count indices of links (L), total link strength (TLS), and citations (C). The TGCS in HistCite Pro is the same as C in VOSviewer and they are, therefore, merged.

\begin{tabular}{|c|c|c|c|c|c|c|}
\hline No. & Items & $\mathbf{N}$ & TLCS & TGCS/C & $\mathbf{L}$ & TLS \\
\hline \multicolumn{7}{|c|}{ Top 10 authors } \\
\hline 1 & Lai, Yuanming (Chinese Academy of Science, China) & 19 & 76 & 326 & 8 & 26 \\
\hline 2 & Zhao, Lin (Chinese Academy of Science, China) & 17 & 44 & 345 & 9 & 38 \\
\hline 3 & Ma, Wei (Chinese Academy of Science, China) & 15 & 41 & 261 & 8 & 16 \\
\hline 4 & Shur, Yuri (University of Alaska, United States) & 11 & 37 & 484 & 7 & 21 \\
\hline 5 & Zhang, Mingyi (Chinese Academy of Science, China) & 11 & 65 & 276 & 5 & 18 \\
\hline 6 & Niu, Fujun (Chinese Academy of Science, China) & 11 & 26 & 176 & 4 & 13 \\
\hline 7 & Horton, Robert (Iowa State University, United States) & 11 & 18 & 111 & 4 & 25 \\
\hline 8 & Bockheim, Jams G (University of Wisconsin, United States) & 10 & 22 & 522 & 2 & 7 \\
\hline 9 & Kokelj, Steven V (Carleton University, Canada) & 10 & 51 & 361 & 1 & 7 \\
\hline 10 & Burn, C R (Carleton University, Canada) & 9 & 58 & 401 & 1 & 7 \\
\hline \multicolumn{7}{|c|}{ Top 10 organizations } \\
\hline 1 & Chinese Academy of Science, China & 143 & 313 & 2066 & 34 & 135 \\
\hline 2 & University of Alaska, United States & 53 & 109 & 1960 & 33 & 50 \\
\hline 3 & University of Chinese Academy of Sciences, China & 49 & 98 & 539 & 10 & 72 \\
\hline 4 & Russian Academy of Sciences, Russia & 25 & 22 & 336 & 10 & 17 \\
\hline 5 & University of Laval, Canada & 20 & 30 & 535 & 9 & 13 \\
\hline 6 & Hokkaido University, Japan & 17 & 49 & 318 & 5 & 12 \\
\hline 7 & University of Alberta, Canada & 16 & 45 & 431 & 14 & 19 \\
\hline 8 & University of Washington, United States & 16 & 64 & 1123 & 9 & 14 \\
\hline 9 & University of Saskatchewan, Canada & 16 & 69 & 379 & 10 & 15 \\
\hline 10 & University of Colorado, United States & 16 & 43 & 420 & 15 & 23 \\
\hline \multicolumn{7}{|c|}{ Top 10 countries } \\
\hline 1 & China & 270 & 487 & 3180 & 15 & 108 \\
\hline 2 & United States & 223 & 629 & 7509 & 20 & 157 \\
\hline 3 & Canada & 127 & 320 & 3201 & 20 & 77 \\
\hline 4 & Japan & 48 & 231 & 1347 & 7 & 40 \\
\hline 5 & Russia & 47 & 42 & 753 & 14 & 51 \\
\hline 6 & Germany & 33 & 57 & 870 & 15 & 47 \\
\hline 7 & Sweden & 26 & 166 & 1124 & 17 & 44 \\
\hline 8 & Switzerland & 25 & 168 & 910 & 11 & 25 \\
\hline 9 & France & 22 & 28 & 565 & 14 & 29 \\
\hline 10 & Italy & 18 & 10 & 380 & 14 & 27 \\
\hline
\end{tabular}




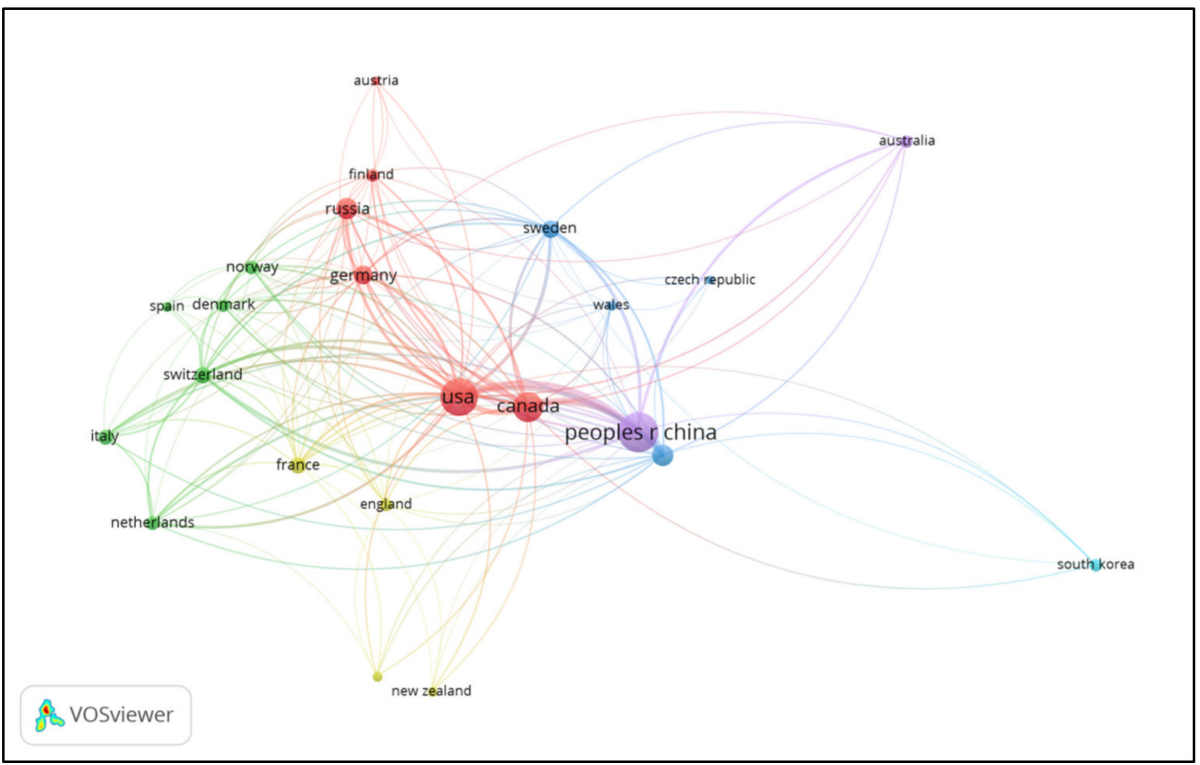

Figure 3. The citation network of 23 countries with minimum five publications (VOSviewer 1.6.15). The size of the circle and font in the map depend on the degree of nodes, the strength of links, and the amount of citations. The color of the circle represented [sic] the cluster to which it belonged, and the cluster was represented [sic] by different colors.

\subsection{The Most Recognized Journals}

There are 217 journals that published 719 publications on UWFS, with the top 10 journals accounting for $38.66 \%$ of the total publications (278, Figure 4). The most utilized journal is Cold Regions Science and Technology that published 103 papers on UWFS, followed by Permafrost and Periglacial Processes and Water Resources Research (Figure 4). The study of frozen soil and unfrozen water is of great significance in engineering [68,69], mechanics [70,71], and water resources or hydrology [72,73] in cold regions. It is understandable that these three journals carried a significantly higher volume of such studies compared to other journals. It should also be noted that there are two open-access journals, The Cryosphere that was launched in 2007 focusing on all aspects of frozen soils and ground on Earth and on other planetary bodies, while the Vadose Zone Journal that was published under the Open Access model since late 2017 has special sections focusing on cold region hydrology and frozen soil processes. These journals are expected to play an increasingly significant role in promoting frozen soil studies.

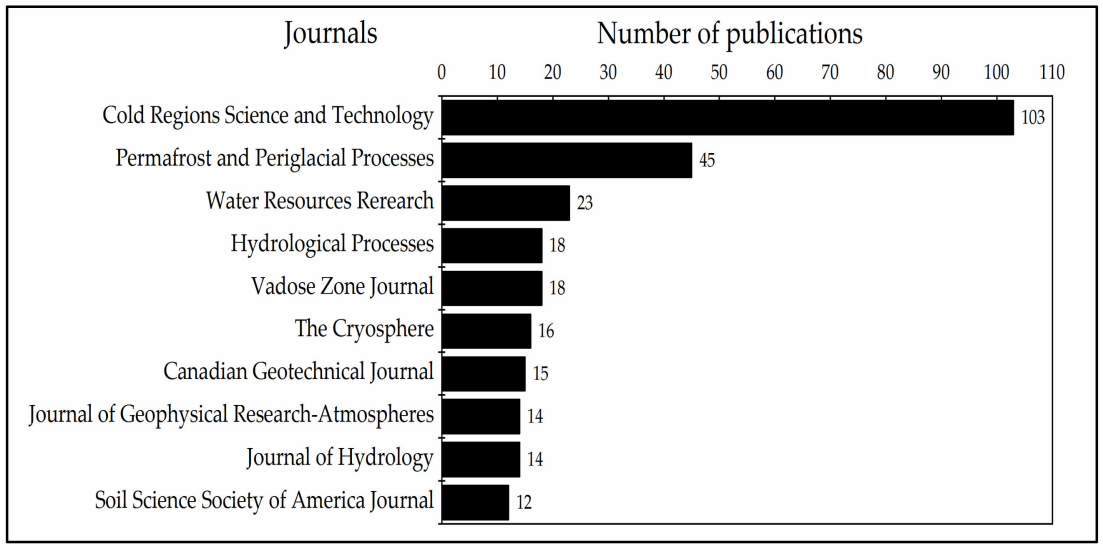

Figure 4. Top 10 journals published studies on unfrozen water in frozen soils (UWFS) from 1992 to 2020 based on Web of Science Core Collection. 


\subsection{The High-Impact Studies}

Figure 5 shows the top 30 cited publications pertaining to UWFS using HistCite Pro, the number in each box within the figure references the paper's order in the database used for analysis. Examining the use of time domain reflectometry for measuring liquid water content in frozen soil (number 28, Figure 5) [39], which establishes a relationship between time-domain-reflectometry (TDR)-measured dielectric permittivity and gas-dilatometermeasured unfrozen water content, is the most cited publication. The method described in this article advances use of the TDR method in frozen soil studies, but the relationship (TDR to gas-dilatometry) is dependent on soil and known total water content (i.e., unfrozen water and ice content), for which there is no universal relationship $[13,14,16]$. Similarly, other articles in the top 30 cited list presented in Figure 5, e.g., the paper of 30 [60], 31 [74], 206 [40], and 352 [75] focus on the calibration of, or applications of, TDR in measuring unfrozen water content. In addition, publications referencing methods such as nuclear magnetic resonance (NMR) [40], Gamma-ray attenuation [75], and heat pulse (article 247) [76] to measure unfrozen water content and soil freezing characteristics were also highly cited. The papers of 143 [77], 54 [78], 57 [79], 105 [80], 129 [81], 152 [82], 247 [76], and 279 [83] incorporated effects of unfrozen soil water into heat transfer processes to better understand the characteristics of soil freezing and thawing processes and frozen soil permeability or infiltrability. However, the mechanisms defining the magnitude of unfrozen water content still remain unclear and more studies are required [84].

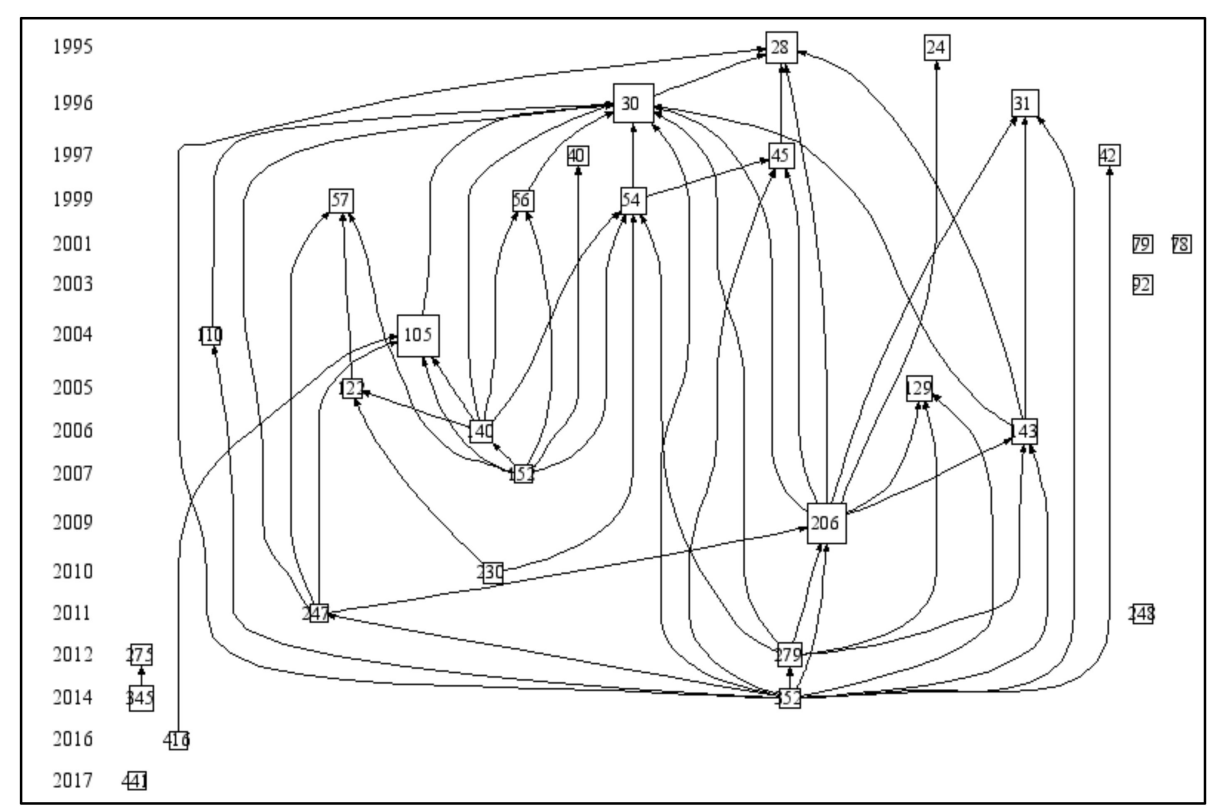

Figure 5. The citation (TLCS) analysis map of the top 30 publications on unfrozen water in frozen soils (UWFS) using HistCite Pro based on data retrieved from the Web of Science Core Collection. The left column is the year that corresponds to the node on the horizontal line. Each node represents a publication, and the number within represents the paper's order in the database used for analysis in the HistCite Pro. The size of the node corresponds to the number of citations, while the arrows represent the citation's relationship to other publications in the list; more arrows indicate more connectivity to other citations.

\subsection{Co-Occurrence Analysis of Keywords}

Figure 6 is a cluster density visualization map of keywords in the literature on unfrozen soil water research using VOSviewer 1.6.15. There are 114 keywords that occur more than 10 times. They are grouped into six clusters by VOSviewer that qualitatively show six research fields. For instance, the green-colored cluster mainly focuses on "permafrost" in "Qinghai-Tibet Plateau", "Alaska", "Canada", "Mackenzie Delta" under "climate change". The blue-colored cluster is related to "snow cover" or "snow" and their effects on "soil 
moisture" (as well as its measurement as indicated by "dielectric constant"), and "runoff". While the pink-colored cluster is characterized with soil mechanics and numerical modeling as indicated by keywords of "frost heave", "creep", "movement", "shear strength", "tensile strength", "strength", and "model".

Figure 7 reflects the development and evolution of trending topics in the research of UWFS between 1992 and 2020. For example, "Time domain reflectometry" (TDR) is a convenient and accurate method for measuring soil water content that has been in use since the $1980 \mathrm{~s}$, and has become the predominant method for assessing soil moisture starting in the $1990 \mathrm{~s}$. It is the keyword with the earliest and longest burst time, which indicates that this method had been widely used to measure unfrozen soil water content $[12,13,15,16,39,74,75,85,86]$. Other keywords including "porous media", "coupled heat" and "permittivity" are also related to the measurement of soil moisture content (Figure 7). "Frost", "permafrost", and "movement" [87] are keywords that have been concerned for a long period of time as indicated by their longer red lines. The research regions and climate type are "Alaska" [88], "Canada" [89], and "tundra" during the 2000s. In the 2010s, more problems [90,91] tend to run numerical "simulation" with "land surface model" by investigating "mass transfer", "thermal regime", and "coupled heat". The engineering-related "behavior", "thaw", or "vulnerability" of frozen soil or "embankment" terms also gained much attention [92,93]. Quantitative research on the relationship between frozen soil moisture content and soil mechanical stability is of guiding significance to the development of engineering construction. The interaction between climate change and the release of biochar from permafrost, and permafrost change has also attracted the attention of researchers. Examples associated with this may include the destruction of the subarctic landscape in northern Sweden [94,95] and the emergence of pink glaciers in the Alps $[96,97]$ that are the manifestations of permafrost degradation and also a warning to mankind.

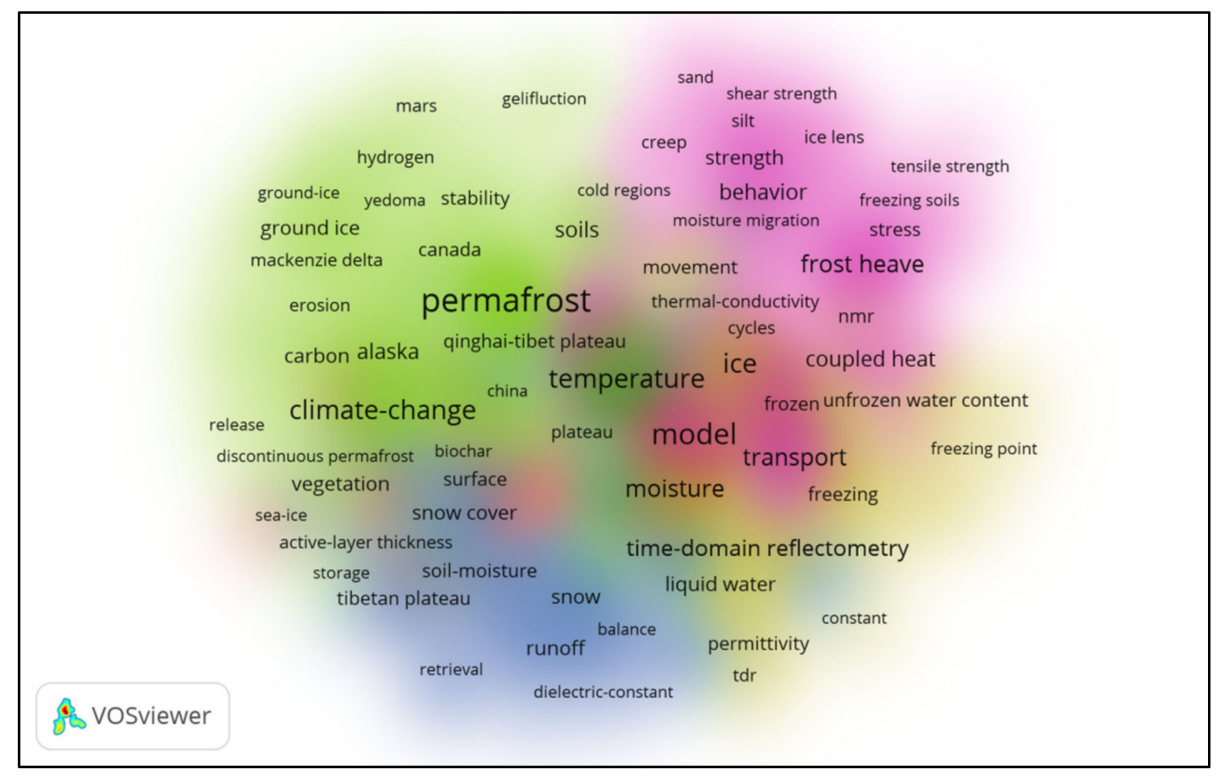

Figure 6. Cluster density visualization map of 105 keywords each occurs more than 10 times in the title, abstract, and keyword list (produced by VOSviewer1.6.15). Note: Font size and density (background color) of keywords are used to represent the total link strength (TLS). Greater font size [sic] indicates greater TLS, and TLS. The distances [sic] between each of the keywords indicate the relatedness of these research topics. 


\begin{tabular}{|c|c|c|c|}
\hline \multicolumn{4}{|c|}{ Top 50 Keywords with the Strongest Citation Bursts } \\
\hline \multirow{2}{*}{$\begin{array}{l}\text { Keywords } \\
\text { time domain reflectometr }\end{array}$} & \multicolumn{2}{|c|}{ Year Strength Begin End } & $1992-2020$ \\
\hline & 1992 & 2.403419932013 & \\
\hline infiltration & 1992 & 2.272519941997 & \\
\hline soil & 1992 & 5.376119942005 & \\
\hline heat & 1992 & 2.715219951996 & \\
\hline water & 1992 & 3.258519972002 & \\
\hline frost & 1992 & 3.176519972011 & \\
\hline salt & 1992 & 2.626219972002 & \\
\hline field & 1992 & 2.6919972000 & \\
\hline movement & 1992 & 3.491320002013 & \\
\hline permafrost & 1992 & 6.877520012007 & \\
\hline tundra & 1992 & 3.141720012005 & \\
\hline alaska & 1992 & 2.924320012005 & \\
\hline frozen soil & 1992 & 2.621120022004 & \\
\hline canada & 1992 & 2.619420042012 & \\
\hline ice & 1992 & 5.055920042009 & \\
\hline unfrozen water & 1992 & 2.75820042006 & \\
\hline active layer & 1992 & 2.305420062007 & \\
\hline flow & 1992 & 2.655620062011 & \\
\hline model & 1992 & 2.268520062007 & \\
\hline variability & 1992 & 2.323720072012 & \\
\hline fluxe & 1992 & 2.543320092014 & \\
\hline thermal property & 1992 & 3.154620102015 & \\
\hline carbon & 1992 & 2.949220102017 & \\
\hline hydraulic conductivity & 1992 & 2.313920102012 & \\
\hline water content & 1992 & 2.397820102011 & \\
\hline degradation & 1992 & 2.857220112012 & \\
\hline organic matter & 1992 & 2.700320112013 & \\
\hline climate & 1992 & 4.422220112016 & \\
\hline northwest territory & 1992 & 2.86720122013 & \\
\hline unsaturated soil & 1992 & 2.505720122013 & \\
\hline thermal regime & 1992 & 2.839220122017 & \\
\hline mass transfer & 1992 & 3.156720122017 & \\
\hline liquid water & 1992 & 3.617420132014 & \\
\hline ice content & 1992 & 3.183120132016 & \\
\hline porous media & 1992 & 3.273920132018 & \\
\hline coupled heat & 1992 & 3.170820142016 & \\
\hline system & 1992 & 2.277820142015 & \\
\hline vulnerability & 1992 & 2.928120142015 & \\
\hline ground ice & 1992 & 2.500720142016 & \\
\hline parameterization & 1992 & 3.424120152018 & \\
\hline land surface model & 1992 & 2.278220152018 & \\
\hline snow & 1992 & 2.794620152016 & \\
\hline simulation & 1992 & 3.819620162018 & \\
\hline soil moisture & 1992 & 4.459820162017 & \\
\hline thaw & 1992 & 2.925120172018 & \\
\hline permittivity & 1992 & 3.036720172018 & \\
\hline region & 1992 & 2.660520172018 & \\
\hline behavior & 1992 & 3.678520182020 & \\
\hline conductivity & 1992 & 3.055920182020 & \\
\hline embankment & 1992 & 2.336820182020 & \\
\hline
\end{tabular}

Figure 7. The strongest citation bursts map showed the top 50 keywords in frozen soil from 1992 to 2020 by CiteSpace. Blue indicates the time when keywords appear, and red indicates the time when keywords burst.

\section{Conclusions and Perspectives}

Publications on unfrozen water in frozen soil (UWFS) were analyzed by scientometric analysis from 1992 to 2020 based on data from the Web of Science Core Collection. Our analysis shows that the publication trend for research of UWFS can be divided into two periods. Prior to 2007, there was slow, but steady progress in the field ( $<20$ publications per year), but thereafter, it appears there was an almost explosive interest in UWFS as the average annual number of publications on the subject increased almost 5-fold by 2020. Clearly, there was a renewed interest in UWFS that paralleled broader societal concerns regarding climate change and frozen landscapes. The United States, China, and Canada 
make the greatest contributions and have relatively high influence on this research field. At present, subjects on UWFS focus primarily on the measurement and modeling techniques, initiation of projects in frozen soil regions, and the impact of climate change on permafrost degradation. Scientometric analysis is an effective tool for visualization of unfrozen water research status in frozen soil.

In recent decades, great progress and breakthroughs have been made in the measurement of unfrozen water content. For instance, although NMR is not a widely-used method, it has been used successfully in both lab- and field-scale measurements of frozen ground, both with borehole tools as well as surface methods that offer a greater depth of investigation at lower resolution. It is noteworthy that determination of ice content presents a great challenge, but there are promising measurements combining neutron logging with gamma-gamma logs to distinguish ice content stratigraphy [75,98]. However, applications of these tools are challenged by the access and use of strictly regulated radioactive-sources. There is still a lack of ease of use, portable, and reliable method for accurate measurement of unfrozen water content both in laboratory and in-situ and no single method can be used to simultaneously measure both unfrozen water and ice content. The recently developed heat pulse method and its combination with time/frequency domain reflectometry method may provide a solution for this [15,99-101]. Mechanisms for determining the magnitude of unfrozen soil water content in frozen soils are still not clear and models used to predict unfrozen water content or soil freezing/thawing characteristics are still at their infancy [84,102]. In addition, more studies are required to understand how unfrozen soil water content and the increased freeze-thaw cycles would affect microbial activity, carbon and nitrogen cycles and the associated greenhouse gas emission, thickness of active layers $[103,104]$, and landscape change [62,105-107] under climate change.

Author Contributions: Conceptualization, H.H.; methodology, H.H. and S.F.; software, S.F. and H.Z.; validation, J.L. and M.D.; writing-original draft preparation, S.F., H.Z. and H.H.; writing-review and editing, J.L., Q.W. and H.H.; funding acquisition, J.L., M.D., Q.W. and H.H. All authors have read and agreed to the published version of the manuscript.

Funding: Funding for this research was provided in part by the National Natural Science Foundation of China (41877015, 42077135), Natural Science Foundation of Shaanxi Province (2020JM-169), China Postdoctoral Science Foundation (2018M641024), the State Key Laboratory of Frozen Soil Engineering (SKLFSE201905), the Northwest A\& F University (Youth Talent Training Program), and the 111 project (Grant No. B12007).

Institutional Review Board Statement: Not applicable.

Informed Consent Statement: Not applicable.

Data Availability Statement: Data is available upon request.

Acknowledgments: The authors also greatly appreciate the valuable and insightful comments by anonymous reviewers.

Conflicts of Interest: The authors declare that they have no known competing financial interests or personal relationships that could have appeared to influence the work reported in this paper.

\section{References}

1. Zhang, T.J. Influence of the seasonal snow cover on the ground thermal regime: An overview. Rev. Geophys. 2005, 43. [CrossRef]

2. Ouyang, W.; Lai, X.H.; Li, X.; Liu, H.Y.; Lin, C.Y.; Hao, F.H. Soil respiration and carbon loss relationship with temperature and land use conversion in freeze-thaw agricultural area. Sci. Total Environ. 2015, 533, 215-222. [CrossRef]

3. Pradhan, N.R.; Downer, C.W.; Marchenko, S. Catchment hydrological modeling with soil thermal dynamics during seasonal freeze-thaw cycles. Water 2019, 11, 116. [CrossRef]

4. Zhang, Y.; Johnson, A.E.; White, D.J. Freeze-thaw performance of cement and fly ash stabilized loess. Transp. Geotech. 2019, 21, 10. [CrossRef]

5. Zhang, T.; Barry, R.G.; Armstrong, R.L. Application of satellite remote sensing techniques to frozen ground studies. Polar Geogr. 2004, 28. [CrossRef]

6. Nelson, F.E.; Anisimov, O.A.; Shiklomanov, N.I. Climate change and hazard zonation in the circum-Arctic permafrost regions. Nat. Hazards 2002, 26, 203-225. [CrossRef] 
7. Anderson, D.M.; Tice, A.R. Predicting unfrozen water contents in frozen soils from surface area measurements. Highw. Res. Rec. 1972, 393, 12-18.

8. Ishizaki, T.; Maruyama, M.; Furukawa, Y.; Dash, J.G. Premelting of ice in porous silica glass. J. Cryst Growth 1996, 163, 455-460. [CrossRef]

9. Cannell, G.H.; Gardner, W.H. Freezing-point depressions in stabilized soil aggregates, synthetic soil, and quartz sand. Soil Sci. Soc. of Am. J. 1959, 23, 418-422. [CrossRef]

10. Suzuki, S. Verification of freezing point depression method for measuring matric potential of soil water. Soil Sci. Plant. Nutr. 2004, 50, 1277-1280. [CrossRef]

11. Henry, H.A.L. Climate change and soil freezing dynamics: Historical trends and projected changes. Clim. Chang. 2008, 87, 421-434. [CrossRef]

12. Christensen, A.F.; He, H.; Dyck, M.; Lenore Turner, E.; Chanasyk, D.S.; Naeth, M.A.; Nichol, C. In situ measurement of snowmelt infiltration under various topsoil cap thicknesses on a reclaimed site. Can. J. Soil Sci. 2013, 93, 497-510. [CrossRef]

13. He, H.; Dyck, M. Application of multiphase dielectric mixing models for understanding the effective dielectric permittivity of frozen soils. Vadose Zone J. 2013, 12. [CrossRef]

14. He, H.; Dyck, M.; Si, B.; Zhang, T.; Lv, J.; Wang, J. Soil freezing-thawing characteristics and snowmelt infiltration in Cryalfs of Alberta, Canada. Geoderma Reg. 2015, 5, 198-208. [CrossRef]

15. He, H.; Dyck, M.; Wang, J.; Lv, J. Evaluation of TDR for quantifying heat-pulse-method-induced ice melting in frozen soils. Soil Sci. Soc. Am. J. 2015, 79, 1275-1288. [CrossRef]

16. He, H.; Dyck, M.; Zhao, Y.; Si, B.; Jin, H.; Zhang, T.; Lv, J.; Wang, J. Evaluation of five composite dielectric mixing models for understanding relationships between effective permittivity and unfrozen water content. Cold Reg. Sci. Technol. 2016, 130, 33-42. [CrossRef]

17. He, H.; Flerchinger, G.; Kojima, Y.; Dyck, M.; Lv, J. A review and evaluation of 39 thermal conductivity models for frozen soils. Geoderma 2021, 382, 114694. [CrossRef]

18. He, H.; He, D.; Jin, J.; Smits, K.M.; Dyck, M.; Wu, Q.; Si, B.; Lv, J. Room for improvement: A review and evaluation of 24 soil thermal conductivity parameterization schemes commonly used in land-surface, hydrological, and soil-vegetation-atmosphere transfer models. Earth Sci. Rev. 2020, 211, 103419. [CrossRef]

19. Walvoord, M.A.; Kurylyk, B.L. Hydrologic impacts of thawing permafrost-A review. Vadose Zone J. 2016, 15, 20. [CrossRef]

20. Kok, H.; McCool, K.D. Quantifying freeze/thaw-induced variability of soil strength. Trans. Asae 1990, 33, 501-0506. [CrossRef]

21. Matsumoto, M.; Saito, S.; Ohmine, I. Molecular dynamics simulation of the ice nucleation and growth process leading to water freezing. Nature 2002, 416, 409-413. [CrossRef] [PubMed]

22. Zhang, M.Y.; Zhang, X.Y.; Xu, X.T.; Lu, J.G.; Pei, W.S.; Xiao, Z.A. Water-heat migration and frost-heave behavior of a saturated silty clay with a water supply. Exp. Heat Transf. 2017, 30, 517-529. [CrossRef]

23. Xu, J.; Wang, S.H.; Wang, Z.Q.; Jin, L.; Yuan, J. Heat transfer and water migration in loess slopes during freeze-thaw cycling in northern Shaanxi, China. Int. J. Civ. Eng. 2018, 16, 1591-1605. [CrossRef]

24. Mu, C.; Abbott, B.W.; Norris, A.J.; Mu, M.; Fan, C.; Chen, X.; Jia, L.; Yang, R.; Zhang, T.; Wang, K.; et al. The status and stability of permafrost carbon on the Tibetan Plateau. Earth Sci. Rev. 2020, 211, 103433. [CrossRef]

25. Zhang, D.F.; Wang, S.J. Mechanism of freeze-thaw action in the process of soil salinization in northeast China. Environ. Geol. 2001, 41, 96-100. [CrossRef]

26. Wu, D.Y.; Zhou, X.Y.; Jiang, X.Y. Water and salt migration with phase change in saline soil during freezing and thawing processes. Groundwater 2018, 56, 742-752. [CrossRef]

27. Brown, D.R.N.; Jorgenson, M.T.; Douglas, T.A.; Romanovsky, V.E.; Kielland, K.; Hiemstra, C.; Euskirchen, E.S.; Ruess, R.W. Interactive effects of wildfire and climate on permafrost degradation in Alaskan lowland forests. J. Geophys. Res. Biogeosci. 2015, 120, 1619-1637. [CrossRef]

28. Nicolsky, D.J.; Romanovsky, V.E. Modeling long-term permafrost degradation. J. Geophys. Res. Earth Surf. 2018, $123,1756-1771$. [CrossRef]

29. Sun, Z.; Zhao, L.; Hu, G.J.; Qiao, Y.P.; Du, E.J.; Zou, D.F.; Xie, C.W. Modeling permafrost changes on the Qinghai-Tibetan plateau from 1966 to 2100: A case study from two boreholes along the Qinghai-Tibet engineering corridor. Permafr. Periglac. Process. 2020, 31, 156-171. [CrossRef]

30. Li, G.Y.; Yu, Q.H.; Ma, W.; Chen, Z.Y.; Mu, Y.H.; Guo, L.; Wang, F. Freeze-thaw properties and long-term thermal stability of the unprotected tower foundation soils in permafrost regions along the Qinghai-Tibet Power Transmission Line. Cold Reg. Sci. Technol. 2016, 121, 258-274. [CrossRef]

31. Niu, F.J.; Li, A.Y.; Luo, J.; Lin, Z.J.; Yin, G.A.; Liu, M.H.; Zheng, H.; Liu, H. Soil moisture, ground temperatures, and deformation of a high-speed railway embankment in northeast China. Cold Reg. Sci. Technol. 2017, 133, 7-14. [CrossRef]

32. Brouchkov, A.; Fukuda, M. Preliminary measurements on methane content in permafrost, Central Yakutia, and some experimental data. Permafr. Periglac. Process. 2002, 13, 187-197. [CrossRef]

33. Wu, Q.B.; Zhu, Y.L.; Liu, Y.Z. Evaluating model of frozen soil environment change under engineering actions. Sci. China Ser. D Earth Sci. 2002, 45, 893-902. [CrossRef]

34. Ouyang, W.; Shan, Y.S.; Hao, F.H.; Chen, S.Y.; Pu, X.; Wang, M.K. The effect on soil nutrients resulting from land use transformations in a freeze-thaw agricultural ecosystem. Soil Tillage Res. 2013, 132, 30-38. [CrossRef] 
35. Bronfenbrener, L.; Bronfenbrener, R. Modeling frost heave in freezing soils. Cold Reg. Sci. Technol. 2010, 61, 43-64. [CrossRef]

36. Caicedo, B. Physical modelling of freezing and thawing of unsaturated soils. Geotechnique 2017, 67, 106-126. [CrossRef]

37. Schuur, E.A.G.; Mack, M.C. Ecological response to permafrost thaw and consequences for local and global ecosystem services. Annu. Rev. Ecol. Evol. Syst. 2018, 49, 279-301. [CrossRef]

38. Tanski, G.; Couture, N.; Lantuit, H.; Eulenburg, A.; Fritz, M. Eroding permafrost coasts release low amounts of dissolved organic carbon (DOC) from ground ice into the nearshore zone of the Arctic Ocean. Glob. Biogeochem. Cycles 2016, 30, 1054-1068. [CrossRef]

39. Spaans, E.J.A.; Baker, J.M. Examining the use of time domain reflectometry for measuring liquid water content in frozen soil. Water Resour. Res. 1995, 31, 2917-2925. [CrossRef]

40. Watanabe, K.; Wake, T. Measurement of unfrozen water content and relative permittivity of frozen unsaturated soil using NMR and TDR. Cold Reg. Sci. Technol. 2009, 59, 34-41. [CrossRef]

41. Suzuki, S.; Kitamura, S. Unfrozen water in amylosic molecules is dependent on the molecular structures-A differential scanning calorimetric study. Food Hydrocoll. 2008, 22, 862-867. [CrossRef]

42. Patterson, D.E.; Smith, M.W. The use of time domain reflectometry for the measurement of unfrozen water content in frozen soils. Cold Reg. Sci. Technol. 1980, 3, 205-210. [CrossRef]

43. Bittelli, M.; Flury, M.; Roth, K. Use of dielectric spectroscopy to estimate ice content in frozen porous media. Water Resour. Res. 2004, 40, W04212. [CrossRef]

44. Xie, H.L.; Zhang, Y.W.; Wu, Z.L.; Lv, T.G. A bibliometric analysis on land degradation: Current status, development, and future directions. Land 2020, 9, 37. [CrossRef]

45. Zhang, H.L.; Liu, X.Y.; Yi, J.; Yang, X.F.; Wu, T.I.; He, Y.; Duan, H.; Liu, M.X.; Tian, P. Bibliometric analysis of research on soil water from 1934 to 2019. Water 2020, 12, 15. [CrossRef]

46. He, D.; Bristow, K.; Filipović, V.; Lv, J.; He, H. Microplastics in terrestrial ecosystems: A scientometric analysis. Sustainability 2020, 12, 8739. [CrossRef]

47. He, H.; Dyck, M.; Lv, J. The heat pulse method for soil physical measurements: A bibliometric analysis. Appl. Sci. 2020, $10,6171$. [CrossRef]

48. Van Eck, N.J.; Waltman, L. Software survey: VOSviewer, a computer program for bibliometric mapping. Scientometrics 2010, 84, 523-538. [CrossRef] [PubMed]

49. Chen, C.M. Searching for intellectual turning points: Progressive knowledge domain visualization. Proc. Natl. Acad. Sci. USA 2004, 101, 5303-5310. [CrossRef]

50. Garfield, E.; Paris, S.W.; Stock, W.G. HistCite ${ }^{\mathrm{TM}}$ : A software tool for informetric analysis of citation linkage. Inf. Wiss. Und Prax. 2006, 57, 391.

51. Lucio-Arias, D.; Leydesdorff, L. Main-path analysis and path-dependent transitions in HistCite ${ }^{\mathrm{TM}}$-based historiograms. J. Assoc. Inf. Sci. Technol. 2008, 59, 1948-1962. [CrossRef]

52. Prideaux, B.; McKercher, B.; McNamara, K.E. Modelling a tourism response to climate change using a four stage problem definition and response framework. Asia Pac. J. Tour. Res. 2013, 18, 165-182. [CrossRef]

53. Christoff, P. The Bali roadmap: Climate change, COP 13 and beyond. Environ. Politics 2008, 17, 466-472. [CrossRef]

54. Wu, M. Coupled Processes in Seasonally Frozen Soils: Merging Experiments and Simulations; KTH Royal Institute of Technology: Stockholm, Sweden, 2016.

55. Zhang, T.; Barry, R.G.; Knowles, K.; Heginbottom, J.A.; Brown, J. Statistics and characteristics of permafrost and ground-ice distribution in the Northern Hemisphere. Polar Geogr. 2008, 31, 47-68. [CrossRef]

56. Frauenfeld, O.W.; Zhang, T.J.; Barry, R.G.; Gilichinsky, D. Interdecadal changes in seasonal freeze and thaw depths in Russia. J. Geophys. Res. Atmos. 2004, 109. [CrossRef]

57. Halsey, L.A.; Vitt, D.H.; Zoltai, S.C. Disequilibrium response of permafrost in boreal continental western Canada to climate-change. Clim. Chang. 1995, 30, 57-73. [CrossRef]

58. Talamucci, F. Freezing processes in porous media: Formation of ice lenses, swelling of the soil. Math. Comput. Model. 2003, 37, 595-602. [CrossRef]

59. Talamucci, F. Freezing processes in saturated soils. Math. Models Meth. Appl. Sci. 1998, 8, 107-138. [CrossRef]

60. Spaans, E.J.A.; Baker, J.M. The soil freezing characteristic: Its measurement and similarity to the soil moisture characteristic. Soil Sci. Soc. Am. J. 1996, 60, 13-19. [CrossRef]

61. Donohoe, J.F.; Maishman, D.; Schmall, P.C. The Freezing of Soil Masses as an Aid to Engineering Construction; American Society of Civil Engineers: New York, NY, USA, 1998; pp. 149-160.

62. Niu, F.J.; Cheng, G.D.; Ni, W.K.; Jin, D.W. Engineering-related slope failure in permafrost regions of the Qinghai-Tibet Plateau. Cold Reg. Sci. Technol. 2005, 42, 215-225. [CrossRef]

63. Jin, H.J.; Wei, Z.; Wang, S.L.; Yu, Q.H.; Lue, L.Z.; Wu, Q.B.; Ji, Y.J. Assessment of frozen-ground conditions for engineering geology along the Qinghai-Tibet highway and railway, China. Eng. Geol. 2008, 101, 96-109. [CrossRef]

64. Niu, F.J.; Lin, Z.J.; Lu, J.H.; Liu, H.; Xu, Z.Y. Characteristics of roadbed settlement in embankment-bridge transition section along the Qinghai-Tibet Railway in permafrost regions. Cold Reg. Sci. Technol. 2011, 65, 437-445. [CrossRef]

65. Zhang, X.; Lai, Y.; Yu, W.; Wu, Y. Forecast analysis for the re-frozen of Feng Huoshan permafrost tunnel on Qing-Zang railway. Tunn. Undergr. Space Technol. 2004, 19, 45-56. [CrossRef] 
66. Wu, X.; Niu, F.; Lin, Z.; Luo, J.; Zheng, H.; Shao, Z. Delamination frost heave in embankment of high speed railway in high altitude and seasonal frozen region. Cold Reg. Sci. Technol. 2018, 153, 25-32. [CrossRef]

67. Peng, H.; Ma, W.; Mu, Y.-h.; Jin, L.; Yuan, K. Degradation characteristics of permafrost under the effect of climate warming and engineering disturbance along the Qinghai-Tibet Highway. Nat. Hazards 2015, 75, 2589-2605. [CrossRef]

68. Tounsi, H.; Rouabhi, A.; Tijani, M.; Guerin, F. Thermo-hydro-mechanical modeling of artificial ground freezing: Application in mining engineering. Rock Mech. Rock Eng. 2019, 52, 3889-3907. [CrossRef]

69. Wang, P.S.; Zhou, G.Q. Frost-heaving pressure in geotechnical engineering materials during freezing process. Int. J. Min. Sci. Technol. 2018, 28, 287-296. [CrossRef]

70. Aleksyutina, D.; Ogorodov, S.; Shilova, O. Simulation of coastal dynamics at the Kara Sea. J. Coast. Res. 2020, 95, 330-335. [CrossRef]

71. Bai, R.Q.; Lai, Y.M.; You, Z.M.; Ren, J.G. Simulation of heat-water-mechanics process in a freezing soil under stepwise freezing. Permafr. Periglac. Process. 2020, 31, 200-212. [CrossRef]

72. Gao, B.; Yang, D.; Qin, Y.; Wang, Y.; Li, H.; Zhang, Y.; Zhang, T. Change in frozen soils and its effect on regional hydrology, upper Heihe basin, northeastern Qinghai-Tibetan Plateau. Cryosphere 2018, 12, 657-673. [CrossRef]

73. Hongkai, G.; Jingjing, W.; Yuzhong, Y.; Xicai, P.; Yongjian, D.; Zheng, D. Permafrost hydrology of the Qinghai-Tibet Plateau: A review of processes and modeling. Front. Earth Sci. 2021, 8, 576838.

74. Seyfried, M.S.; Murdock, M.D. Calibration of time domain reflectometry for measurement of liquid water in frozen soils. Soil Sci. 1996, 161, 87-98. [CrossRef]

75. Zhou, X.; Zhou, J.; Kinzelbach, W.; Stauffer, F. Simultaneous measurement of unfrozen water content and ice content in frozen soil using gamma ray attenuation and TDR. Water Resour. Res. 2014, 50, 9630-9655. [CrossRef]

76. Liu, G.; Si, B.C. Soil ice content measurement using a heat pulse probe method. Can. J. Soil Sci. 2011, 91, 235-246. [CrossRef]

77. Flerchinger, G.N.; Seyfried, M.S.; Hardegree, S.P. Using soil freezing characteristics to model multi-season soil water dynamics. Vadose Zone J. 2006, 5, 1143-1153. [CrossRef]

78. Stahli, M.; Jansson, P.E.; Lundin, L.C. Soil moisture redistribution and infiltration in frozen sandy soils. Water Resour. Res. 1999, 35, 95-103. [CrossRef]

79. Cherkauer, K.A.; Lettenmaier, D.P. Hydrologic effects of frozen soils in the upper Mississippi River basin. J. Geophys. Res. Atmos. 1999, 104, 19599-19610. [CrossRef]

80. Hansson, K.; Simunek, J.; Mizoguchi, M.; Lundin, L.C.; van Genuchten, M.T. Water flow and heat transport in frozen soil: Numerical solution and freeze-thaw applications. Vadose Zone J. 2004, 3, 693-704. [CrossRef]

81. Yoshikawa, K.; Overduin, P.P. Comparing unfrozen water content measurements of frozen soil using recently developed commercial sensors. Cold Reg. Sci. Technol. 2005, 42, 250-256. [CrossRef]

82. Zhang, X.; Sun, S.F.; Xue, Y.K. Development and testing of a frozen soil parameterization for cold region studies. J. Hydrometeorol. 2007, 8, 690-701. [CrossRef]

83. Wen, Z.; Ma, W.; Feng, W.J.; Deng, Y.S.; Wang, D.Y.; Fan, Z.S.; Zhou, C.L. Experimental study on unfrozen water content and soil matric potential of Qinghai-Tibetan silty clay. Environ. Earth Sci. 2012, 66, 1467-1476. [CrossRef]

84. Jin, X.; Yang, W.; Gao, X.; Zhao, J.-Q.; Li, Z.; Jiang, J. Modeling the unfrozen water content of frozen soil based on the absorption effects of clay surfaces. Water Resour. Res. 2020, 56, e2020WR027482. [CrossRef]

85. Smith, M.W.; Tice, A.R. Measurement of the Unfrozen Water Content of Soils: A Comparison of NMR and TDR Methods; Cold Regions Research and Engineering Laboratory: Hanover, NH, USA, 1988; p. 16.

86. Rydén, B.E. Winter soil moisture regime monitored by the time domain reflectometry technique (TDR). Geogr. Ann. Ser. A Phys. Geogr. 1986, 68, 175-184.

87. Harris, C.; Lewkowicz, A.G. An analysis of the stability of thawing slopes, Ellesmere Island, Nunavut, Canada. Can. Geotech. J. 2000, 37, 449-462. [CrossRef]

88. Hinkel, K.M.; Doolittle, J.A.; Bockheim, J.G.; Nelson, F.E.; Paetzold, R.; Kimble, J.M.; Travis, R. Detection of subsurface permafrost features with ground-penetrating radar, Barrow, Alaska. Permafr. Periglac. Process. 2001, 12, 179-190. [CrossRef]

89. Mackay, J.R.; Burn, C.R. The first 20 years (1978-1979 to 1998-1999) of active-layer development, Illisarvik experimental drained lake site, western Arctic coast, Canada. Can. J. Earth Sci. 2002, 39, 1657-1674. [CrossRef]

90. Hayashi, M.; Goeller, N.; Quinton, W.L.; Wright, N. A simple heat-conduction method for simulating the frost-table depth in hydrological models. Hydrol. Process. 2007, 21, 2610-2622. [CrossRef]

91. Overduin, P.P.; Kane, D.L.; van Loon, W.K.P. Measuring thermal conductivity in freezing and thawing soil using the soil temperature response to heating. Cold Reg. Sci. Technol. 2006, 45, 8-22. [CrossRef]

92. Ma, W.; Mu, Y.H.; Wu, Q.B.; Sun, Z.Z.; Liu, Y.Z. Characteristics and mechanisms of embankment deformation along the Qinghai-Tibet Railway in permafrost regions. Cold Reg. Sci. Technol. 2011, 67, 178-186. [CrossRef]

93. Qin, Y.H.; Zhang, J.M.; Zheng, B.; Ma, X.J. Experimental study for the compressible behavior of warm and ice-rich frozen soil under the embankment of Qinghai-Tibet Railroad. Cold Reg. Sci. Technol. 2009, 57, 148-153. [CrossRef]

94. Callaghan, T.V.; Jonasson, C.; Thierfelder, T.; Yang, Z.; Hedenas, H.; Johansson, M.; Molau, U.; Van Bogaert, R.; Michelsen, A.; Olofsson, J.; et al. Ecosystem change and stability over multiple decades in the Swedish subarctic: Complex processes and multiple drivers. Philos. Trans. R. Soc. B Biol. Sci. 2013, 368, 20120488. [CrossRef] [PubMed] 
95. Fuchs, M.; Kuhry, P.; Hugelius, G. Low below-ground organic carbon storage in a subarctic Alpine permafrost environment. Cryosphere 2015, 9, 427-438. [CrossRef]

96. van der Kolk, H.-J.; Heijmans, M.M.P.D.; van Huissteden, J.; Pullens, J.W.M.; Berendse, F. Potential Arctic tundra vegetation shifts in response to changing temperature, precipitation and permafrost thaw. Biogeosciences 2016, 13, 6229-6245. [CrossRef]

97. Wilkman, E.; Zona, D.; Tang, Y.F.; Gioli, B.; Lipson, D.A.; Oechel, W. Temperature response of respiration across the heterogeneous landscape of the Alaskan Arctic tundra. J. Geophys. Res. Biogeosci. 2018, 123, 2287-2302. [CrossRef]

98. Scapozza, C.; Baron, L.; Lambiel, C. Borehole logging in alpine periglacial talus slopes (Valais, Swiss Alps). Permafr. Periglac. Process. 2015, 26, 67-83. [CrossRef]

99. He, H.; Dyck, M.; Horton, R.; Li, M.; Jin, H.J.; Si, B.C. Distributed temperature sensing for soil physical measurements and its similarity to heat pulse method. In Advances in Agronomy; Sparks, D.L., Ed.; Academic Press: Cambridge, UK, 2018. [CrossRef]

100. He, H.; Dyck, M.; Horton, R.; Ren, T.; Bristow, K.L.; Lv, J.; Si, B. Development and application of the heat pulse method for soil physical measurements. Rev. Geophys. 2018, 56, 567-620. [CrossRef]

101. Kojima, Y.; Nakano, Y.; Kato, C.; Noborio, K.; Kamiya, K.; Horton, R. A new thermo-time domain reflectometry approach to quantify soil ice content at temperatures near the freezing point. Cold Reg. Sci. Technol. 2020, 174, 103060. [CrossRef]

102. He, H. Application of Time Domain Reflectometry and Heat Pulse Methods for Quantifying Phase Change, Water Flow and Heat Transport. In Frozen Soils; University of Alberta: Edmonton, AB, Canada, 2015.

103. Pang, Q.Q.; Zhao, L.; Li, S.X.; Ding, Y.J. Active layer thickness variations on the Qinghai-Tibet Plateau under the scenarios of climate change. Environ. Earth Sci. 2012, 66, 849-857. [CrossRef]

104. Kokelj, S.V.; Smith, C.A.S.; Burn, C.R. Physical and chemical characteristics of the active layer and permafrost, Herschel Island, western Arctic Coast, Canada. Permafr. Periglac. Process. 2002, 13, 171-185. [CrossRef]

105. Wang, P.; de Jager, J.; Nauta, A.; van Huissteden, J.; Trofim, M.C.; Limpens, J. Exploring near-surface ground ice distribution in patterned-ground tundra: Correlations with topography, soil and vegetation. Plant. Soil 2019, 444, 251-265. [CrossRef]

106. Chen, J.Y.; Wu, Y.; O'Connor, M.; Cardenas, M.B.; Schaefer, K.; Michaelides, R.; Kling, G. Active layer freeze-thaw and water storage dynamics in permafrost environments inferred from InSAR. Remote Sens. Environ. 2020, 248. [CrossRef]

107. Li, D.S.; Wen, Z.; Cheng, Q.G.; Xing, A.G.; Zhang, M.L.; Li, A.Y. Thermal dynamics of the permafrost active layer under increased precipitation at the Qinghai-Tibet Plateau. J. Mt. Sci. 2019, 16, 309-322. [CrossRef] 